\title{
IMPLEMENTASI UNDANG-UNDANG NOMOR 25 TAHUN 2009 TENTANG PELAYANAN PUBLIK DI KELURAHAN SUKABANGUN
}

\author{
Oleh: Mahendra Kusuma, SH, MH \\ (Dosen Fakultas Hukum Universitas Tamansiswa Palembang) \\ Email : mahendra@unitaspalembang.ac.id
}

\begin{abstract}
ABSTRAK
Masyarakat setiap waktu akan selalu menuntut pelayanan publik yang berkualitas dari birokrat, meskipun tuntutan itu seringkali tidak sesuai dengan apa yang diharapkan, karena secara empiris pelayanan publik yang terjadi selama ini masih menampilkan ciri-ciri yakni berbelit-belit, lambat, mahal, dan melelahkan. Kualitas pelayanan publik merupakan suatu kondisi dimana pelayanan mempertemukan atau memenuhi atau bahkan melebihi dari apa yang menjadi harapan konsumen dengan sistem kinerja aktual dari penyedia jasa. Keberhasilan proses pelayanan publik sangat tergantung pada dua pihak yaitu birokrasi (pelayan) dan masyarakat (yang dilayani).
\end{abstract}

\section{A. Latar Belakang}

Kelurahan adalah wilayah kerja lurah sebagai perangkat daerah kabupaten/daerah kota di bawah kecamatan. Kelurahan merupakan perangkat kecamatan yang dipimpin oleh kepala kelurahan. Pembentukan kelurahan ditetapkan dengan Peraturan Daerah.

Pembentukan kelurahan ditujukan untuk meningkatkan kemampuan penyelenggaraan pemerintahan kelurahan secara berdayaguna, berhasil guna, dan pelayanan terhadap masyarakat sesuai dengan tingkat perkembangan dan kemajuan pembangunan. Pelaksanaan pelayanan publik pada tingkat pemerintah kelurahan merupakan ujung tombak dalam pelayanan prima pada masyarakat. Pemberian pelayanan kepada masyarakat menjadi salah satu aspek paling penting didalam 
pelaksanaan fungsi pemerintahan dimana pemerintah berusaha memberikan pelayanan yang terbaik sebagai implikasi dari fungsi aparatur Negara.

Pelayanan publik adalah terminologi yang biasa di gunakan untuk mengartikan pelayanan yang di sediakan oleh pemerintahan kepada warganya (citizens) juga yang secara langsung melalui sector publik atau melalui ketetapan penganggaran pelyanan sektor swasta. ${ }^{1}$

Masyarakat setiap waktu akan selalu menuntut pelayanan publik yang berkualitas dari birokrat, meskipun tuntutan itu seringkali tidak sesuai dengan apa yang diharapkan, karena secara empiris pelayanan publik yang terjadi selama ini masih menampilkan ciri-ciri yakni berbelit-belit, lambat, mahal, dan melelahkan. ${ }^{2}$

Kualitas pelayanan publik merupakan suatu kondisi dimana pelayanan mempertemukan atau memenuhi atau bahkan melebihi dari apa yang menjadi harapan konsumen dengan sistem kinerja aktual dari penyedia jasa. Keberhasilan proses pelayanan publik sangat tergantung pada dua pihak yaitu birokrasi (pelayan) dan masyarakat (yang dilayani). Dengan demikian untuk melihat kualitas pelayanan publik perlu diperhatikan dan dikaji dua aspek pokok yakni aspek proses internal organisasi birokrasi (pelayan) dan aspek eksternal organisasi yakni kemanfaatan yang dirasakan oleh masyarakat pelanggan. Kualitas memberikan suatu dorongan kepada pelanggan untuk menjalin ikatan yang kuat dengan suatu instansi. Dalam

\footnotetext{
${ }^{1}$ Nurmah Semil, Pelayanan Prima Instansi Pemerintah, Prenadamedia Grup, Jakarta, 2018, hlm. 1

2 Juniarso Ridwan dan Achmad Sodik Sudrajat, Hukum Administrasi Negara dan Kebijakan Pelayanan Publik, Nuansa, bandung, 2009, hlm. 17
} 
jangka panjang ikatan seperti ini memungkinkan suatu instansi memahami dengan seksama harapan pelanggan serta kebutuhan mereka.

Menurut Peraturan Menteri Pendayagunaan Aparatur Negara Dan Reformasi Birokrasi Republik Indonesia Nomor 15 Tahun 2014, komponen standar pelayanan yang terkait dengan proses penyampaian pelayanan meliputi Persyaratan, prosedur, jangka waktu pelayanan, biaya/tarif, produk pelayanan, dan penanganan pengaduan. Jika suatu Instansi pemerintah dan lembaga lainnya mampu menerapkan standar kualitas tersebut maka sudah dapat dikatakan bahwa Instansi pemerintah dan lembaga tersebut telah memberikan kualitas pelayanan yang baik.

Menurut Undang-Undang Nomor 25 Tahun tentang Pelayanan Publik Pelayanan publik adalah segala kegiatan pelayanan yang dilaksanakan oleh penyelenggara pelayanan publik sebagai upaya pemenuhan kebutuhan penerima pelayanan, maupun dalam rangka pelaksanaan ketentuan peraturan perundangundangan.

Pelayanan masyarakat berkaitan dengan pemenuhan kepentingan umum atau publik. Kepentingan umum menjadi dasar dari pelayanan publik karena setiap kegiatan yang dilakukan pemerintah guna memenuhi kepentingan orang banyak pada dasarnya merupakan bentuk pelayanan publik. ${ }^{3}$ Contoh pelayanan publik dalam bentuk pelayanan administrasi yaitu pembuatan KTP (Kartu Tanda Penduduk) dan SKCK (Surat Keterangan Catatan Kepolisian), pelayanan dalam bentuk jasa misalnya

\footnotetext{
3 Dede Mariana dan Caroline Paskarina, Demokrasi dan Politik Desentralisasi, Graha Ilmu, Yogyakarta, 2008, hlm. 316
} 
kantor pos dan bank. Sedangkan pelayanan dalam bentuk barang seperti pembayaran pajak yang digunakan untuk pembangunan infrastuktur negara seperti jembatan dan jalan tol.

Pemerintah daerah wajib membangun manajemen pelayanan publik dengan mengacu pada asas-asas pelayanan publik sesuai dengan Undang-Undang Nomor 23 Tahun 2014 tentang Pemerintahan Daerah. dalam melaksanakan manajemen pelayanan publik, pemerintah daerah dapat membentuk komunikasi antara pemerintah daerah dengan masyarakat dan pemangku kepentingan terkait. ${ }^{4}$

Instansi pemerintah daerah seperti kelurahan merupakan salah satu contoh instansi pemerintah yang melaksanakan pelayanan publik kelurahan sebagai penyedia layanan publik mempunyai tugas pokok membantu Bupati dalam penyelenggaraan pemerintahan, pembangunan dan kemasyarakatan serta meningkatkan efektivitas pelayanan publik dalam rangka penyelenggaraan pemerintahan yang baik (good governance) serta peningkatan kualitas pelayanan dalam bentuk jasa atau perijinan melalui transparasi dan standarisasi pelayanan.

Pelayanan yang baik kepada masyarakat harus didukung oleh pegawaipegawai yang handal, berkompeten, mampu memahami serta dapat melaksanakan tugas pokok dan fungsinya sesuai dengan bidang tanggung jawab yang dibebankan kepadanya. Selain itu, mereka tentu harus memiliki komitmen dan tanggung jawab moral terhadap masyarakat. Masyarakat tentunya ingin mendapatkan kualitas

\footnotetext{
${ }^{4}$ Andi Pangerang Moenta dan Syafa'at Anugrah Pradana, Pokok-Pokok Hukum Pemerintah Daerah, Rajagrafindo Persada, Jakarta, 2018, hlm. 167
} 
pelayanan yang baik dari pemerintah. Pelayanan yang berkualitas atau yang biasa disebut dengan pelayanan prima merupakan pelayanan terbaik yang memenuhi standar kualitas pelayanan.

\section{B. Permasalahan}

Berdasarkan pembatasan masalah di atas, maka dapat disimpulkan masalah sebagai berikut: Bagaimanakah pelaksanaan Undang-Undang Nomor 25 Tahun 2009 Tentang Pelayanan Publik di Kelurahan Sukabangun?

\section{Pembahasan}

Dalam konteks birokrasi, etika birokrasi digambarkan sebagai suatu panduan norma bagi aparat birokrasi dalam menjalankan tugas pelayanan kepada masyarakat, etika birokrasi harus menempatkan kepentingan publik di atas kepentingan pribadi, kelompok, dan organisasinya.

Etika dalam penyelenggaraan pelayanan publik dapat dilihat dari sudut apakah seorang aparat birokrasi dalam memberikan pelayanan kepada masyarakat merasa mempunyai komitmen untuk menghargai hak-hak dari konsumen untuk mendapatkan pelayanan sesuai secara transparan, efisien, dan adanya jaminan kepastian pelayanan. Perilaku aparat birokrasi yang memiliki etika dapat tercermin pada sikap sopan dan keramahan dalam menghadapi masyarakat pengguna jasa.

Dalam penyelenggaraan pelayanan publik, terdapat dua pihak yang berhadapan dan saling berbeda kepentingan. Pihak aparat birokrasi sebagai pemberi pelayanan yang berhadapan dengan masyarakat sebagai pengguna jasa layanan, antara keduanya, seringkali terdapat perbedaan kepentingan yang mencolok. Aparat 
birokrasi pada dasarnya adalah seorang abdi bukannya seorang tuan. Persepsi tersebut selama ini tidak pernah ditanamkan secara sistematis kepada aparat birokrasi. Hal tersebut membawa konsekuensi pada masih munculnya sikap arogansi birokrasi, seperti merasa sebagai pihak yang paling dibutuhkan oleh orang banyak, atau bersikap seenaknya kepada masyarakat. Sikap yang ditunjukkan oleh sebagian besar aparat birokrasi tersebut membuat masyarakat merasa tidak memperoleh pelayanan seperti yang diharapkan, bahkan masyarakat sering kali merasa disepelekan dan tidak diorangkan oleh birokrasi. Kecenderungan yang justru terjadi adalah abdi masyarakat dibalikkan artinya menjadi masyarakat sebagai abdi birokrat.

Menurut Agus Dwiyanto dkk, adanya perbedaan sikap pelayanan secara normatif dengan sikap pelayanan secara faktual yang dilakukan oleh aparat birokrasi terungkap dari banyaknya keluhan yang dirasakan oleh masyarakat pengguna jasa pada saat menerima pelayanan. Pengamatan yang dilakukan di lapangan menunjukkan adanya kecenderungan diskriminasi yang sangat mencolok dalam memberikan pelayanan. Realitas pelayanan menunjukkan bahwa aparat birokrasi dalam kenyataannya melakukan pembedaan pelayanan terhadap masyarakat pengguna jasa. Pembedaan pelayanan tersebut didasarkan atas beberapa hal, antara lain, karena faktor tinggi rendahnya status sosial ekonomi, kedekatan hubungan sosial dengan aparat, penampilan fisik pengguna jasa, etnik, afiliasi politik, afiliasi sosial kemasyarakatan, dan tingkat intelektualitas masyarakat. ${ }^{5}$

\footnotetext{
5 Agus Dwiyanto dkk, Reformasi Birokrasi Publik di Indonesia, Gadjah Mada University Press, Yogyakarta, 2012, hlm. 193
} 
Dalam upaya meminimalisasi kebiasaan yang tidak sehat dan bahkan membuka pintu ke arah perilaku koruptif dalam penyelenggaraan pelayanan publik telah ditetapkan Undang-Undang Nomor 25 Tahun 2009 tentang Pelayanan Publik (UUPP). Secara spesifik Pasal 3 UUPP mengemukakan bahwa tujuan dari UU Pelayanan Publik adalah: (1) terwujudnya batasan dan hubungan yang jelas tentang hak, tanggung jawab, kewajiban, dan kewenangan seluruh pihak yang terkait dengan penyelenggaraan pelayanan publik; (2) terwujudnya sistem pelayanan publik yang layak sesuai dengan asas-asas umum pemerintahan dan korporasi yang baik; (3) terpenuhinya penyelenggaraan pelayanan publik sesuai dengan peraturan perundangundangan, dan (4) terwujudnya perlindungan dan kepastian hukum bagi masyarakat dalam penyelenggaraan pelayanan publik.

Adapun sasaran yang ingin dicapai dengan diterbitkannya UUPP adalah: (1) terwujudnya acuan hukum tentang penyelenggaraan pelayanan publik; (2) terwujudnya kepastian hukum bagi penyelenggaraan penanaman modal (investasi) di Indonesia; (3) terbentuknya dan tersusunnya organisasi penyelenggaraan pelayanan publik yang layak; (4) terlaksanannya pengelolaan sumber daya aparatur penyelenggara pelayanan publik yang efektif, tepat guna dan tepat sasaran; (5) terwujudnya pengawasan dalam penyelenggaraan pelayanan publik; (6) terwujudnya peran serta masyarakat dalam penyelenggaraan pelayanan publik.

Sehingga harapan sekaligus tuntutan masyarakat untuk mendapatkan pelayanan publik yang berkualitas, prosedur yang jelas, cepat dan biaya yang pantas terus mengemuka dalam dinamika perjalanan penyelenggaraan pemerintahan. 
Harapan dan tuntutan tersebut muncul seiring dengan terbitnya kesadaran bahwa warga negara memiliki hak untuk mendapatkan pelayanan yang baik, dan kewajiban pemerintah untuk memberikan pelayanan yang prima.

Gayung bersambut dengan pelaksanaan otonomi daerah, peluang untuk mengembangkan pelayanan publik yang mudah dijangkau dan tepat sasaran, selayaknya mendapat perhatian yang serius. Betapa tidak, bukankah salah satu filosofi penting otonomi daerah adalah mendekatkan pelayanan kepada masyarakat. ${ }^{6}$

Untuk memaksa penyelenggara pelayanan (Aparatur Sipil Negara) memberikan pelayanan yang sebaik-baiknya, maka UUPP mensyaratkan adanya standar pelayanan. Standar pelayanan ini tercantum dalam Pasal 20 dan Pasal 21.

Pasal 20 berbunyi:

(1) Penyelenggara berkewajiban menyusun dan menetapkan standar pelayanan dengan memperhatikan kemampuan penyelenggara, kebutuhan masyarakat, dan kondisi lingkungan.

(2) Dalam menyusun dan menetapkan standar pelayanan sebagaimana dimaksud pada ayat (1), penyelenggara wajib mengikutsertakan masyarakat dan pihak terkait.

(3) Penyelenggara berkewajiban menerapkan standar pelayanan sebagaimana dimaksud pada ayat (1). hlm. 321

${ }^{6}$ Sirajuddin dkk, Hukum Administrasi Pemerintahan Daerah, Setara Press, Malang, 2016, 
(4) Pengikutsertaan masyarakat dan pihak terkait sebagaimana dimaksud pada ayat (2) dilakukan dengan prinsip tidak diskriminatif, terkait langsung dengan jenis pelayanan, memiliki kompetensi dan mengutamakan musyawarah serta memperhatikan keberagaman.

(5) Penyusunan standar pelayanan sebagaimana dimaksud pada ayat (1) dan ayat (2) dilakukan dengan pedoman tertentu yang diatur lebih lanjut dalam peraturan pemerintah.

Pasal 21 berbunyi:

Komponen standar pelayanan sekurang-kurangnya meliputi:

a. Dasar hukum

b. Persyaratan

c. Sistem mekanisme, dan prosedur.

d. Jangka waktu penyelesaian

e. Biaya/tarif.

f. Produk layanan

g. Sarana, prasarana, dan/atau fasilitas.

h. Kompetensi pelaksana.

i. Pengawasan internal

j. Penanganan pengaduan, saran dan masukan.

k. Jumlah pelaksana

1. Jaminan pelayanan yang memberikan kepastian pelayanan dilaksanakan sesuai dengan standar pelayanan. 
m. Jaminan keamanan dan keselamatan pelayanan dalam bentuk komitmen untuk memberikan rasa aman, bebas dari bahaya dan risiko keraguraguan.

n. Evaluasi kinerja pelaksana.

Standar pelayanan publik merupakan standar pelayanan yang wajib di sediakan oleh pemerintah kepada masyarakat. Adanya standar pelayanan publik akan menjamin minimal yang berhak diperoleh warga masyarakat dari pemerintah. Dengan kata lain, standar pelayanan publik merupakan tolok ukur untuk mengukur kinerja penyelenggaraan kewenangan wajib yang berkaitan dengan pelayanan dasar kepada masyarakat seperti: kesehatan, pendidikan, air minum, perumahan, dan lain-lain. Di samping standar pelayanan publik untuk kewenangan wajib, daerah dapat mengembangkan dan menerapkan standar kinerja untuk kewenangan daerah yang lain.

Dengan standar pelayanan publik, akan terjamin kualitas minimal dari suatu pelayanan publik yang dapat dinikmati oleh masyarakat. Dengan demikian, akan terjadi pemerataan pelayanan publik dan terhindar dari kesenjangan pelayanan antar daerah.

Inilah yang menjadi tugas utama pemerintahan, selain sebagai pengumpul pendapatan daerah dan pengaturan ekonomi daerah. Selama publik belum mampu menyelenggarakan urusan atau kebutuhannya secara mandiri, pemerintah berkewajiban untuk menyelenggarakan keperluan itu sesuai tuntutan dan kebutuhan publik sebagai salah satu bentuk pelayanan. Di sini, peran pemerintah melalui 
kebijakan-kebijakannya begitu urgen dalam memfasilitasi terjadinya mekanisme pasar yang benar, sehingga penyimpangan-penyimpangan yang terjadi di pasar dapat dihindari.

Hal yang terlihat dari dampak perubahan paradigma ini ialah pola pelayanan publik. Dari yang kurang partisipatif, kurang akuntabel, kurang efisien, kurang efektif, dan membeda-bedakan, berubah menjadi lebih partisipatif, lebih akuntabel, lebih efisien, lebih efektif, dan tidak membeda-bedakan. Di samping itu, dalam penyelenggaraannya, diselaraskan dengan tantangan dan tuntutan yang ada di lingkungan publik. Dengan begitu, nantinya bisa berdampak pada menguatnya kepuasan publik terhadap pelayanan pemerintah, yang dibarengi dengan menguatnya kontrol dan kontribusi masyarakat dalam penyelenggaraan pemerintahan.

Jika tata kelola pemerintah dan pelayanan publik saat ini belum mampu menaklukkan tantangan tersebut, tentu kita harus segera berubah dan berbenah. Kondisi demikian memaksa aparatur negara untuk bersikap adaptif dan responsif terhadap kondisi masyarakat, tapi dengan tetap melaksanakan prosedur pelayanan yang prima. Pelayanan prima adalah pelayanan yang sangat baik atau pelayanan yang terbaik.

Perkembangan teknologi informasi menuntut pemerintah menggunakan teknologi informasi sebagai sarana pendukung penyelenggaraan pemerintahan, khususnya penyelenggaraan pelayanan publik. Electronic government (e government) adalah salah satu konsep teknologi informasi yang dihadirkan untuk mendukung 
pemerintah dalam menyelenggarakan pelayanan publik secara efektif, efisien, dan transparan.

Negara-negara maju telah menerapkan e-government sebagai sarana utama dalam mewujudkan kinerja pemerintah yang maksimal dalam menjalankan tugas dan kewajiban sebagai aparatur negara. Di negara-negara maju, semua bentuk pelayanan publik diselenggarakan melalui e-goverment sehingga negara-negara maju sangat cepat merespons segala bentuk permasalahan pelayanan publik sehingga berdampak pada percepatan pembangunan negara.

Pemerintah Indonesia telah berupaya mendorong semua lembaga pemerintah untuk menerapkan e-government sebagai sistem pendukung pelayanan publik. Instruksi Presiden Nomor 3 Tahun 2003 tentang Kebijakan dan Strategi Nasional Penerapan E-Government, merupakan bukti dari upaya pemerintah untuk menjadikan e-government sebagai bagian dari sistem penyelenggaraan pemerintahan, khususnya pelayanan publik.

Beberapa lembaga pemerintah, kementerian, pemerintah daerah, dan pemerintahan desa berupaya menerapkan e-government melalui website. Untuk mendukung penerapan e-government melalui website, pemerintah menyiapkan program dan langkah-langkah strategis serta angaran yang cukup untuk mendukung kesuksesan penerapan e-government, bahkan sejumlah pemerintah daerah memiliki visi pembangunan khusus pengembangan e-government. ${ }^{7}$

\footnotetext{
${ }^{7}$ Achmad Nurmandi dkk, Pelayanan Sektor Publik, UMY Press, Yogyakarta, 2018, hlm. 163
} 
Meskipun beberapa pemerintah daerah kabupaten dan kota telah menerapkan egovernment melalui website interaktif, tetapi website interaktif yang disediakan pemda tersebut belum digunakan secara maksimal untuk sarana pelayanan publik.

\section{Kesimpulan.}

Dari uraian yang penulis bahas pada bab sebelumnya, maka penulis menarik kesimpulan sebagai berikut: Pelaksanaan Undang-Undang Nomor 25 Tahun 2009 Tentang Pelayanan Publik di Kelurahan Sukabangun telah dilaksanakan dengan baik. Standar Operasional Prosedur telah diterapkan. Apabila masyarakat membutuhkan pelayanan publik diharuskan membawa surat pengantar dari Ketua RT tempat masyarakat berdomisili, membawa KTP, membawa fotokopi Kartu Keluarga, dan Bukti Pembayaran PBB tahun berjalan. Pelayanan publik yang diberikan pihak kelurahan hanya sebatas memberikan surat pengatar, antara lain surat pengantar permohonan KK, KTP, SKCK, akte kelahiran, ijin usaha dagang, keterangan domisil, dan keterangan waris tanah. Semua proses tanpa dipungut biaya dan lamanya hanya 60 menit tergantung pada kelengkapan berkas.

\section{DAFTAR PUSTAKA}

Achmad Nurmandi dkk, Pelayanan Sektor Publik, UMY Press, Yogyakarta, 2018

Agus Dwiyanto dkk, Reformasi Birokrasi Publik di Indonesia, Gadjah Mada University Press, Yogyakarta, 2012

Andi Pangerang Moenta dan Syafa'at Anugrah Pradana, Pokok-Pokok Hukum Pemerintah Daerah, Rajagrafindo Persada, Jakarta, 2018 
Dede Mariana dan Caroline Paskarina, Demokrasi dan Politik Desentralisasi, Graha Ilmu, Yogyakarta, 2008,

Juniarso Ridwan dan Achmad Sodik Sudrajat, Hukum Administrasi Negara dan Kebijakan Pelayanan Publik, Nuansa, bandung, 2009

Nurmah Semil, Pelayanan Prima Instansi Pemerintah, Prenadamedia Grup, Jakarta, 2018

Sirajuddin dkk, Hukum Administrasi Pemerintahan Daerah, Setara Press, Malang, 2016 